\title{
A concentração da pobreza nas cidades
}

SEMINÁRIO 2: estudo dos textos:

ESCALAS DA DESIGUALDADE URBANA: a Cidade do Rio de Janeiro e as Favelas, de Camila Lima e Silva de Carvalho;

PROJeto E FAVELA, de Laura Machado Mello Bueno.

Doutorando: Bruno Farias

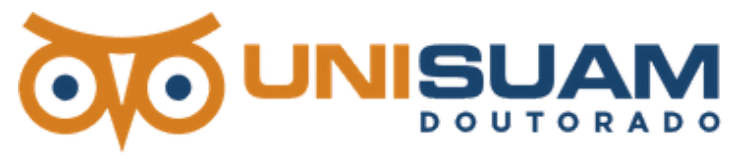
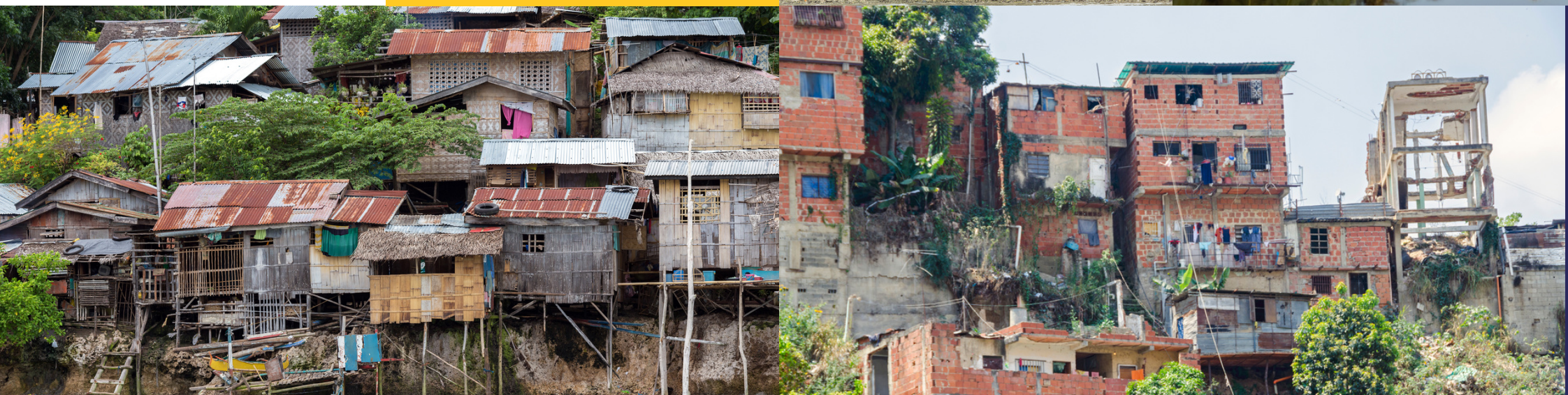

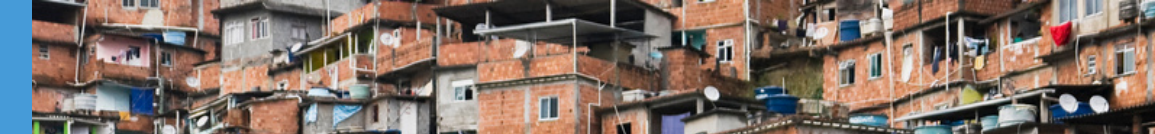
ब.7.

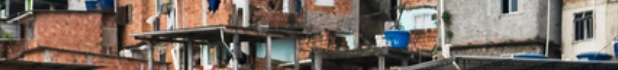

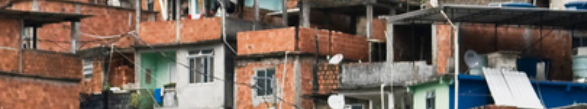

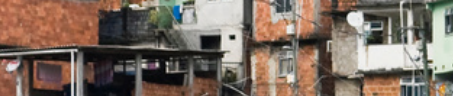
Th- 251 -

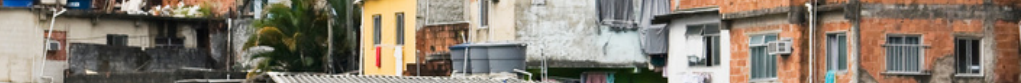

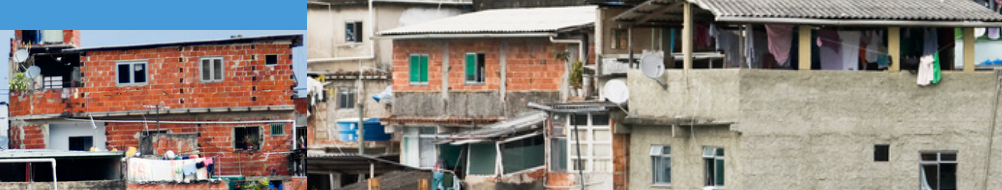
$0 \sqrt{117 ! 9}$
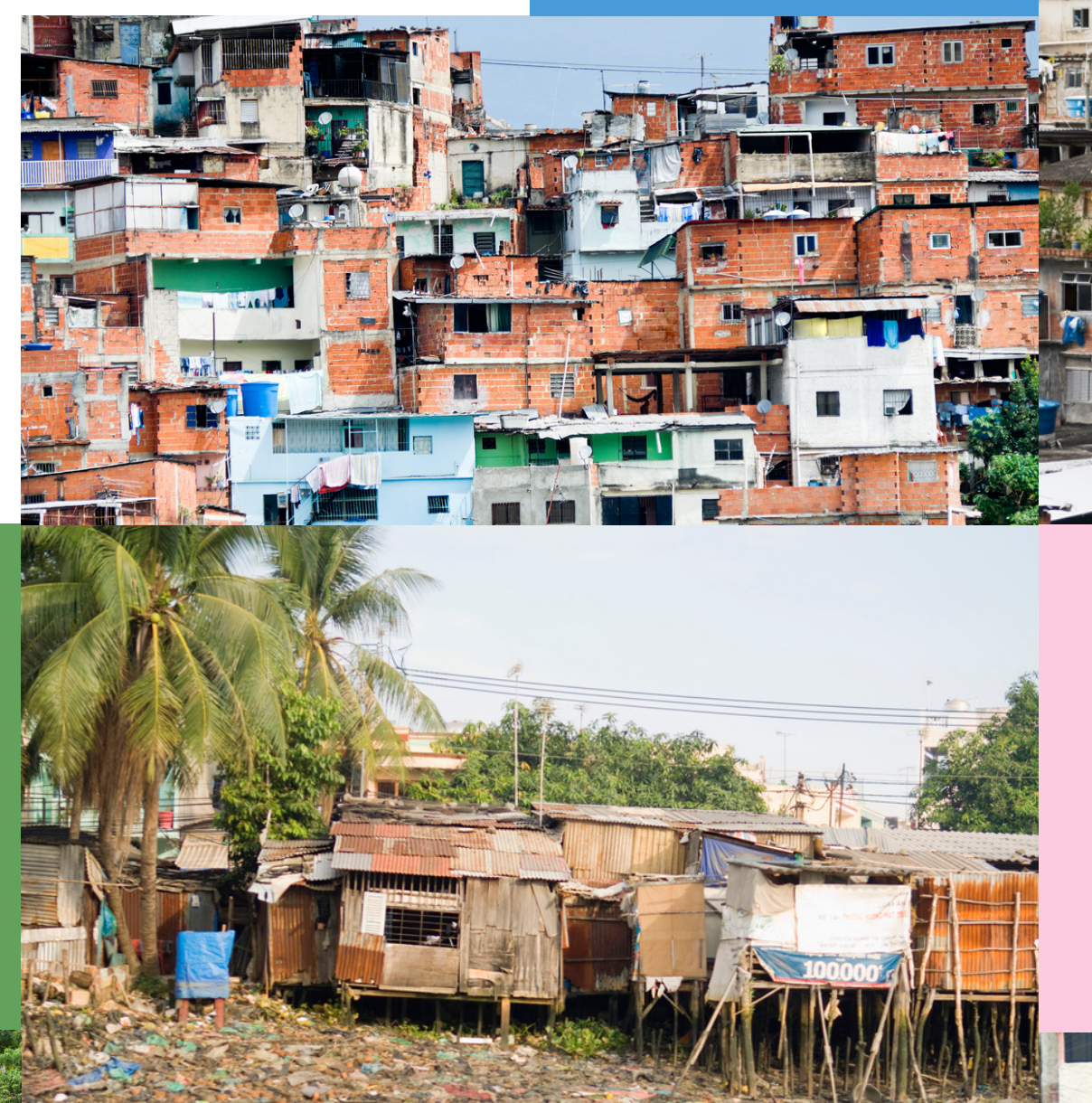

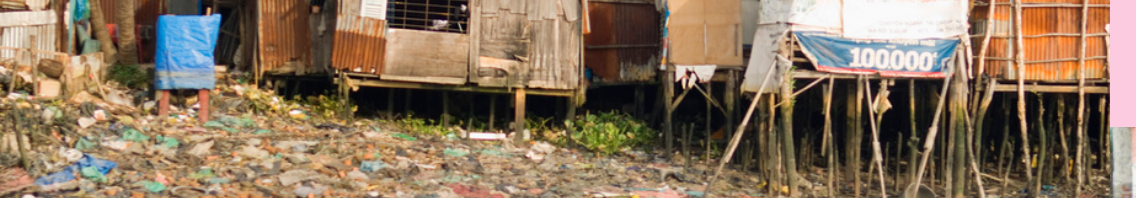
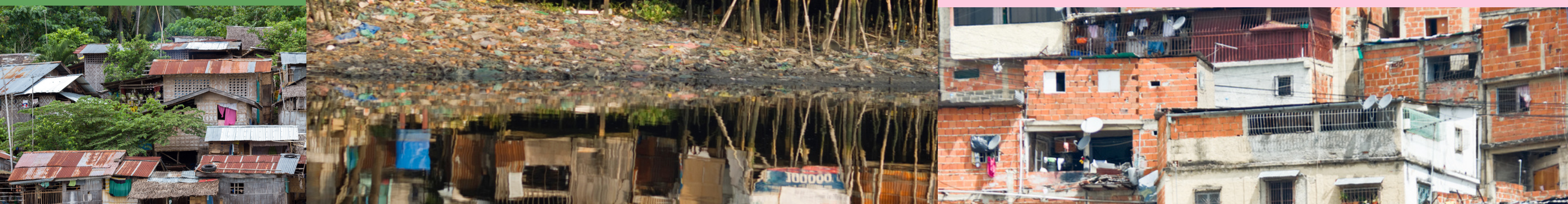
II mand 단.

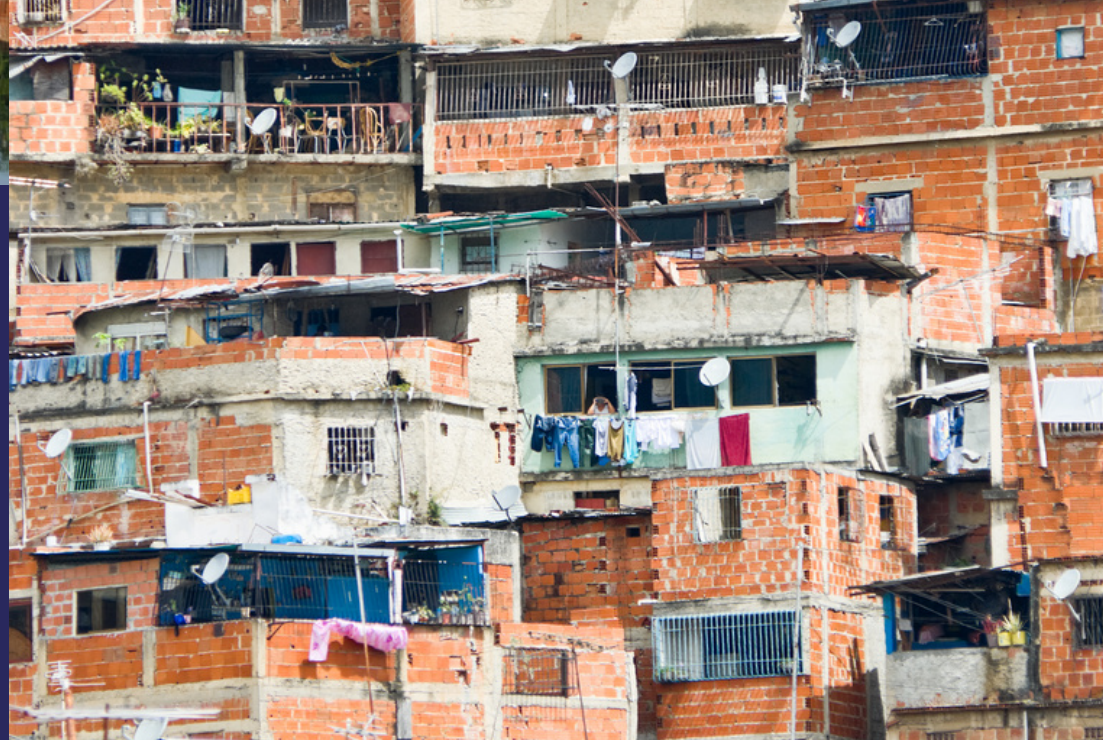




\section{Concentracão de Póbreza}

(BIF)

"50 milhões de brasileiros vivem na linha da pobreza" (IBGE, 2017)

A pobreza é entendida como a carência de bens e serviços sociais. Tem relação direta com a desigualdade na distribuição de renda.

Outra linha de pensamento: A pobreza deve ser compreendida em um contexto social, histórico e cultural (LISTER, 2004).

Amartya Sen (1999) "a pobreza pode ser definida como uma privação das capacidades básicas de um indivíduo e não apenas como uma renda inferior com um patamar pré-estabelecido".

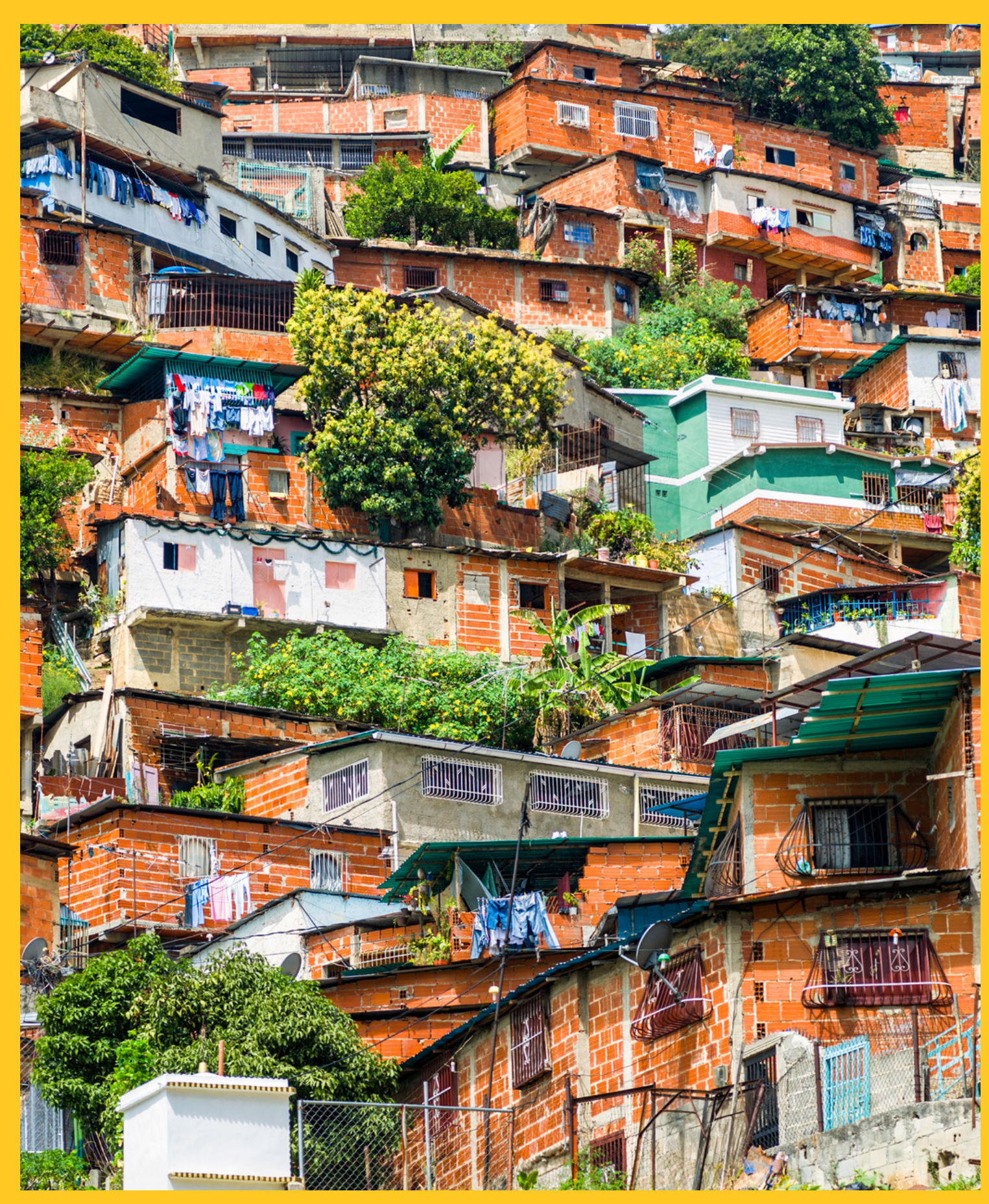

Terminologia usada para definir a pobreza

- Nível baixo de renda ou consumo

- Subdesenvolvimento humano

- Exclusão social

- Vulnerabilidade

- Falta de Recursos

- Necessidades básicas não atingidas

- Privação 


\section{Concentração de}

I.

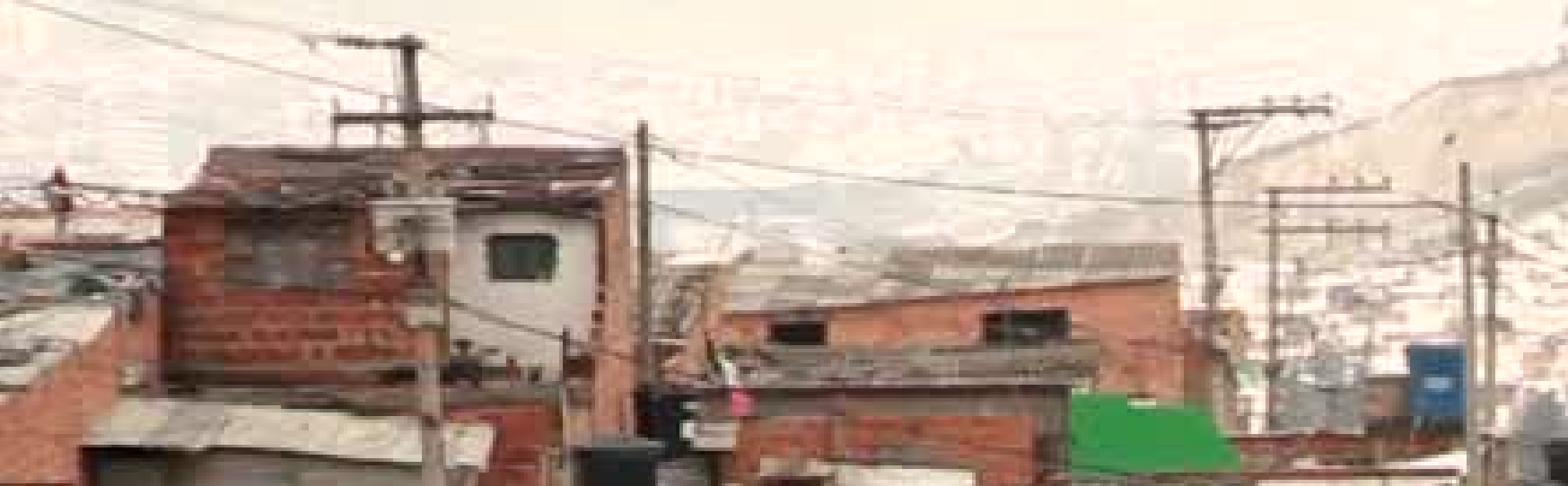

tet.

Pobreza

esto

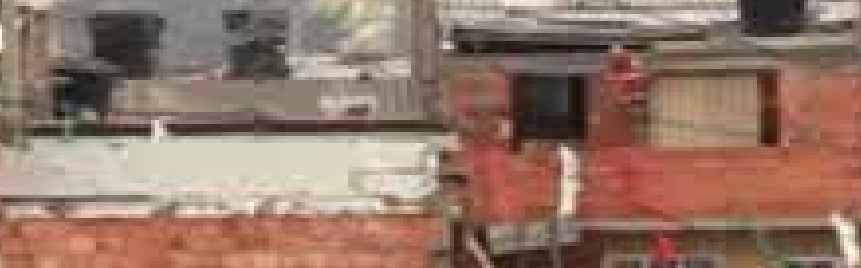

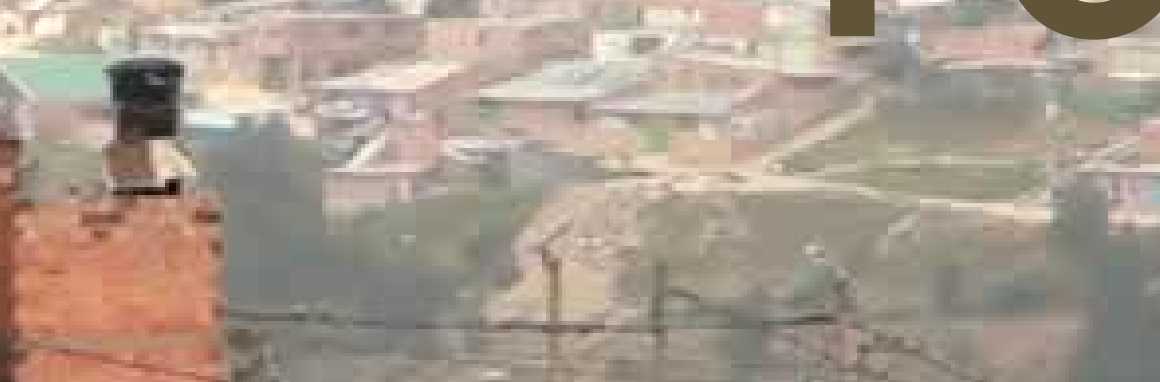
(-)

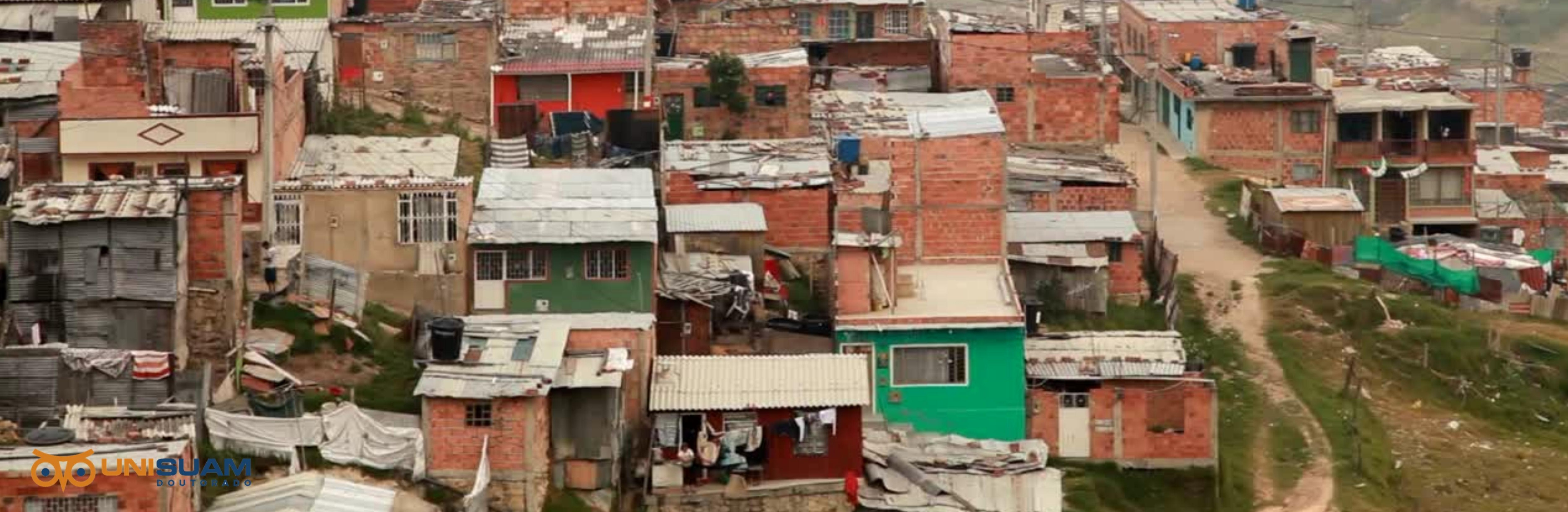


"é preciso reconhecer que a categoria favela foi construída socialmente como um lugar homogêneo da pobreza, da marginalidade e da desorganização social".

(SILVA, 2012)

(...) a sua associação com a pobreza econômica; a falta de formação escolar; a predominância do trabalho manual; o fenótipo dos moradores - em sua maioria - pretos ou pardos; a precariedade das moradias, dos serviços e equipamentos urbanos; a origem nordestina, região considerada 'problema' no país, a ocupação ilegal de terras; a falta de pagamento de taxas e impostos diversos etc.

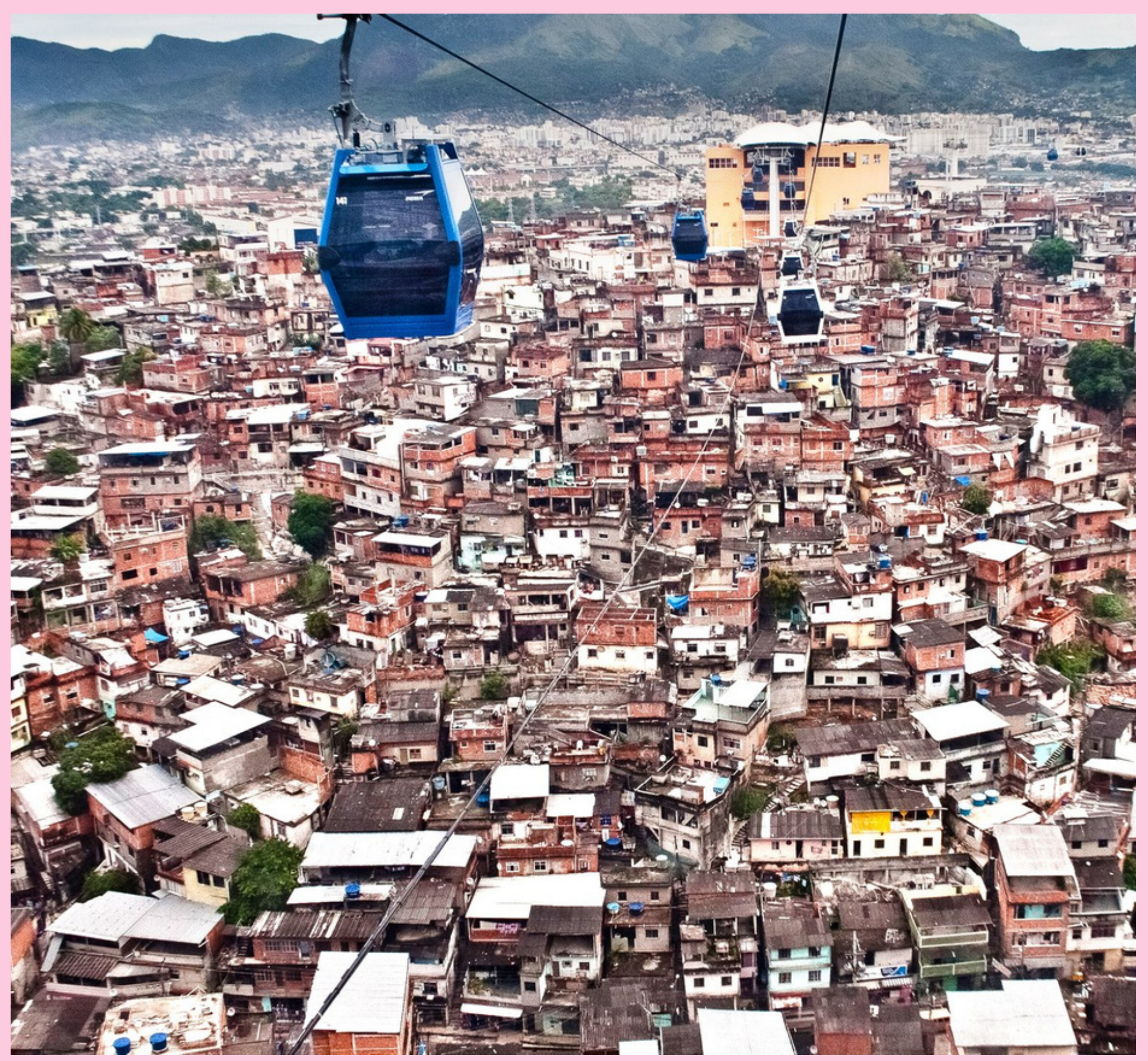

Favela

Complexo do Alemão 


\section{A trajetória da favela}

\section{breve histórico}

Abolição da escravatura

1888
CORTIÇO. Crescimento

exacerbado dos cortiços. $O$

"locus" da pobreza, espaço

onde residiam alguns

trabalhadores e se

concentravam, em grande

número, vadios $\mathrm{e}$

malandros, a chamada

"classe perigosa".

\section{Fim do Séc XIX}

Grande reforma urbana

do prefeito Pereira

Passos, que se

propunha a sanear

e civilizar a cidade

acabando com as

habitações

anti-sanitárias.

$1902-1906$
Criação Programa de

Urbanização de

assentamesntos populares do Rio de Janeiro (Favela-Bairro),

arquiteto Luiz Paulo Conde.

Considerado pelo BID - Banco Interamericano de

Desenvolvimento, como um

projeto modelo de políticas

públicas no combate a

pobreza (38 favelas

reurbanizadas)

1995 (fase1)
Mudança de nome do projeto Favela-Bairro para o (Morar Carioca) Prefeito Eduardo

Paes

2010-2016 (fase3)
1897

Guerra dos canudos

\section{Início do Séc XX}

Três processos de transformação das cidades atuias: A

industrialização da economia A explosão demográfica decorrente da quda das taxas de

mortalidade) e Migração da população do campo para a cidade (em busca de melhores oportunidades de vida)

\section{0-1980}

Aumento populacional de 40milhões para 120milhões de

habitantes e o percentual vivendo em cidades foi de $31 \%$ para $67 \%$. Tais habitantes tinham moradias em regiões desprovidas de infraestrutura e de serviços necessários para caracterizar uma cidade (rua, energia, água coleta de lixo, transporte público, saneamento.)

\section{0-2007 (fase2)}

64 favelas reurbanizadas

\section{7-2020 (fase4)}

6 favelas reurbanizadas, com instituição de um posto de orientação urbanístico e socia (POUSOs) implantado após as obras de urbanização. No local pode ser encontrado um arquiteto ou engenheiro para orientar sobre as normas para as novas construções. 


\section{Favela e Política de Moradia}

A política habitacional desenhada pelo governo militar, a partir da criação do Sistema Financeiro de Habitação (SFH), Lei 4.380, de 21 de agosto de 1964, (que somava os recursos das cadernetas de poupança voluntária, depositados no Sistema Brasileiro de Poupança e Empréstimo, aos da poupança compulsória, depositados no FGTS - Fundo e Garantia por Tempo de Serviço, estes com baixíssima remuneração até o fim dos anos 80 ) e do Banco Nacional de Habitação, foi um importante e poderoso instrumento da política econômica do regime, tanto pela criação de empregos na indústria a construção civil, quanto pelo fortalecimento e modernização deste setor do capital, que tem grande participação do capital nacional.

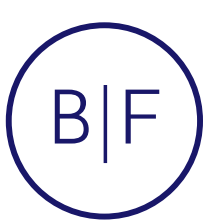

\section{OVUNISUUAM}
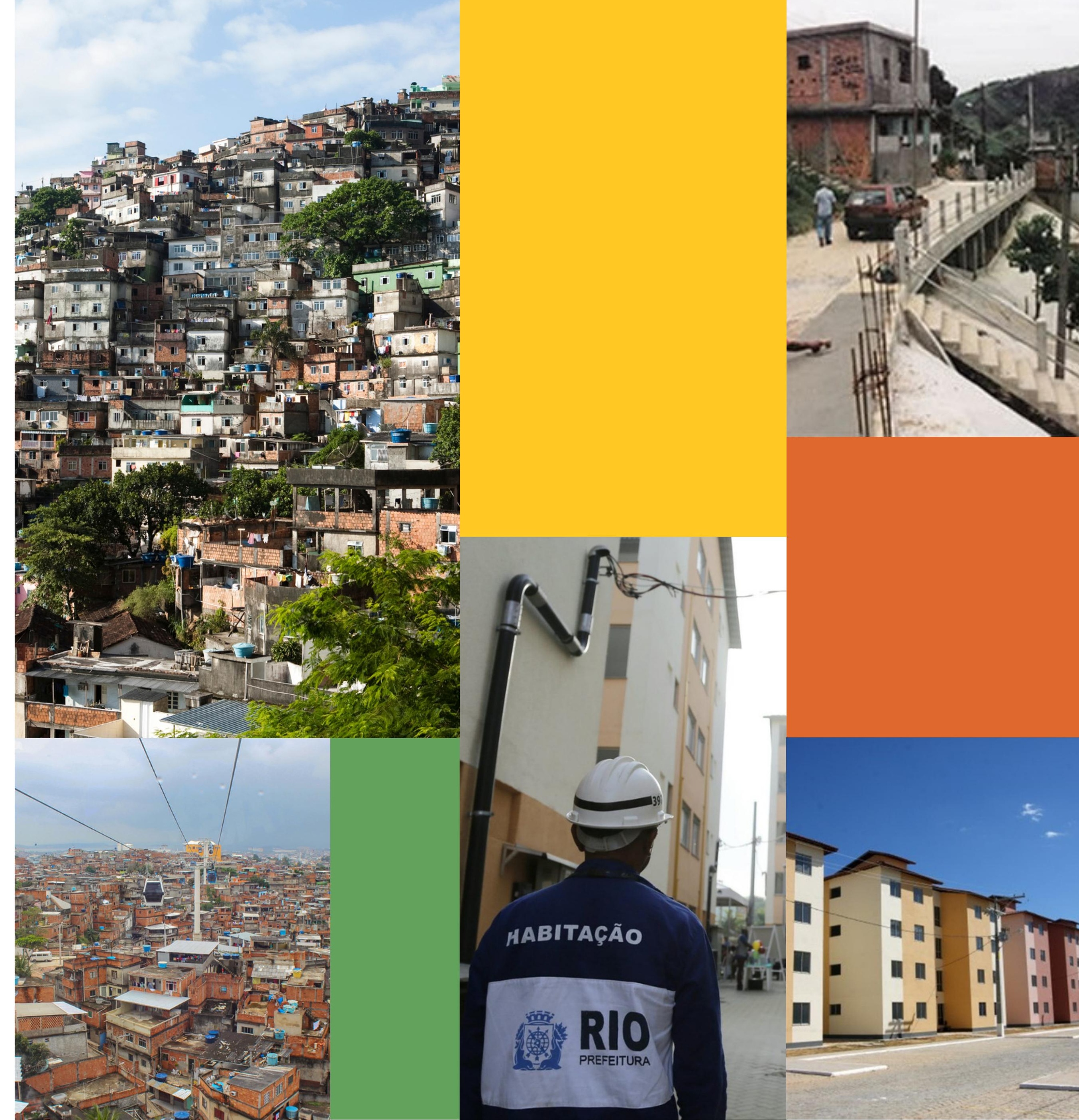
(BIF)

\section{IDH}

O Índice de Desenvolvimento Humano, $\mathrm{IDH}$, reúne três dos requisitos mais importantes para a expansão das liberdades das pessoas: a oportunidade de se levar uma vida longa e saudável saúde - , ter acesso ao conhecimento educação - e poder desfrutar de um padrão de vida digno - renda.

Fonte: IPEA, 2013-2020

\section{Índice de Desenvolvimento Humano Municipal Brasileiro}

\begin{tabular}{|c|c|c|}
\hline \multicolumn{3}{|c|}{ TABELA 4: DESTAQUES DO IDHM 2010} \\
\hline & Município & IDHM \\
\hline \multicolumn{3}{|l|}{ Brasil } \\
\hline Maior IDHM & São Caetano do Sul (SP) & 0,862 \\
\hline Menor IDHM & Melgaço (PA) & 0,418 \\
\hline \multicolumn{3}{|l|}{ Região Norte } \\
\hline Maior IDHM & Palmas (TO) & 0,788 \\
\hline Menor IDHM & Melgaço (PA) & 0,418 \\
\hline \multicolumn{3}{|c|}{ Região Nordeste } \\
\hline Maior IDHM & Fernando de Noronha (PE) & 0,788 \\
\hline Menor IDHM & Fernando Falcão (MA) & 0,443 \\
\hline \multicolumn{3}{|c|}{ Região Centro-0este } \\
\hline Maior IDHM & Brasília (DF) & 0,824 \\
\hline Menor IDHM & Japorã (MS) & 0,526 \\
\hline \multicolumn{3}{|l|}{ Região Sudeste } \\
\hline Maior IDHM & São Caetano do Sul (SP) & 0,862 \\
\hline Menor IDHM & São João das Missões (MG) & 0,529 \\
\hline \multicolumn{3}{|l|}{ Região Sul } \\
\hline Maior IDHM & Florianópolis (SC) & 0,847 \\
\hline Menor IDHM & Doutor Ulysses (PR) & 0,546 \\
\hline
\end{tabular}

Fonte: IPEA, 2020

\author{
> Maior: São Paulo (SP) 0,862 \\ Rio de Janeiro (RJ) $\underline{0}, \underline{799}$ \\ $<$ Menor: Pará $(\mathbf{0 , 4 1 8 )}$


ESCALAS DA DESIGUALDADE URBANA: a Cidade do Rio de Janeiro e as Favelas CAMILA LIMA E SILVA DE CARVALHO

Texto 1

Favelas como o lugar urbano da pobreza;

- Visão da população em relação às favelas, nota-se que o preconceito ainda é muito grande.

Favelas como bolsões de pobreza;

- Pertinente numa determinada estratégia de agregação espacial dos dados censitários - ou seja, uma certa escala geográfica.

Os limites de uma favela individual;

- Mosaico de faixas de renda, a exemplo do observado na escala da cidade.

Estrutura socioespacial diferente da cidade - "Cidades dentro da

cidade";

Indice de Moran (I);

- Compreender a diferenciação entre os clusters (grupos)

Estudo de três agrupamentos de favelas no Rio de Janeiro;

Desigualdade observada na escala da cidade;

Estrutura urbana mais ampla;

As favelas comportam como fractais.

- Determina que uma estrutura esteja, ao mesmo tempo, articulada e no interior de uma estrutura maior, reproduzindo-a.
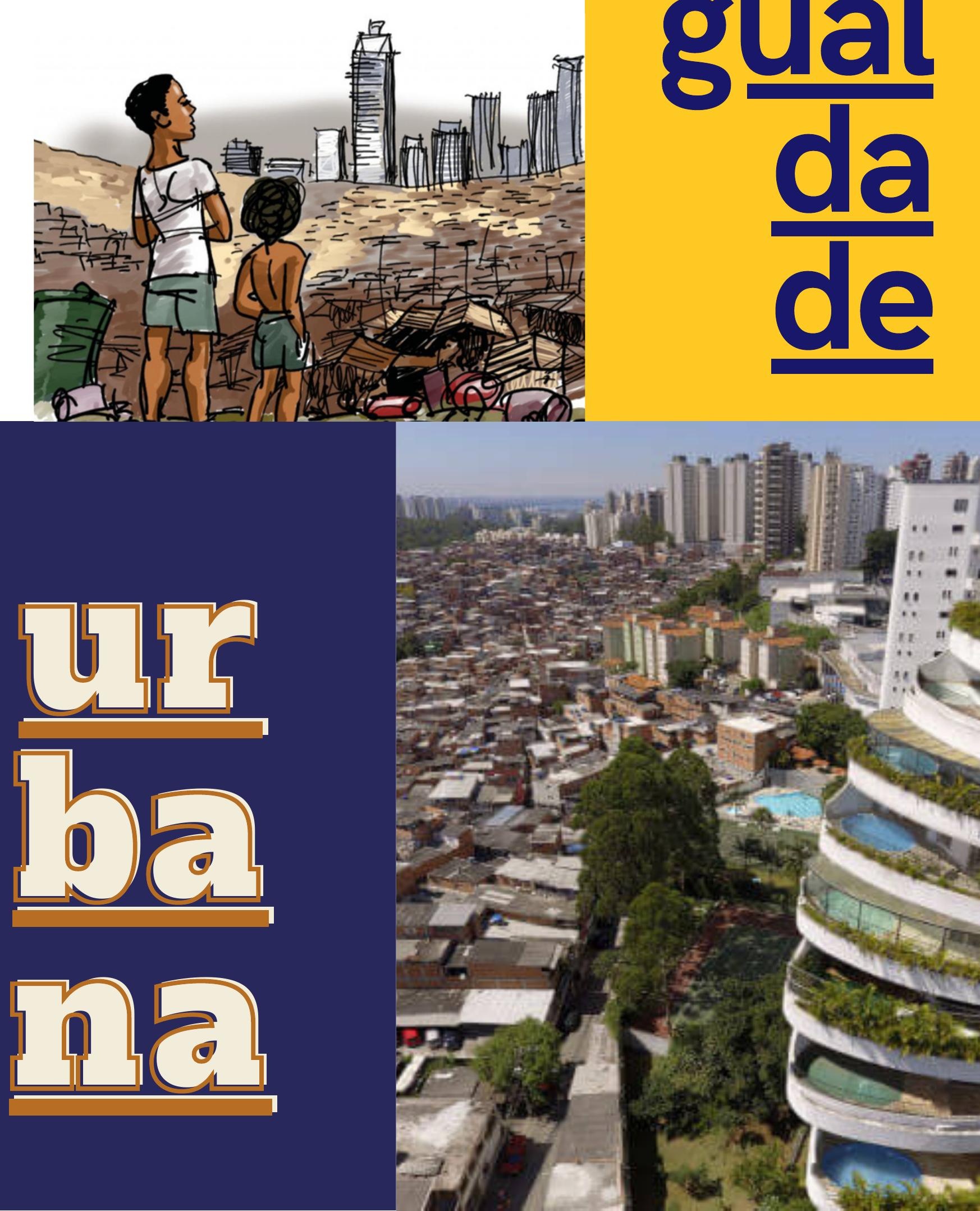


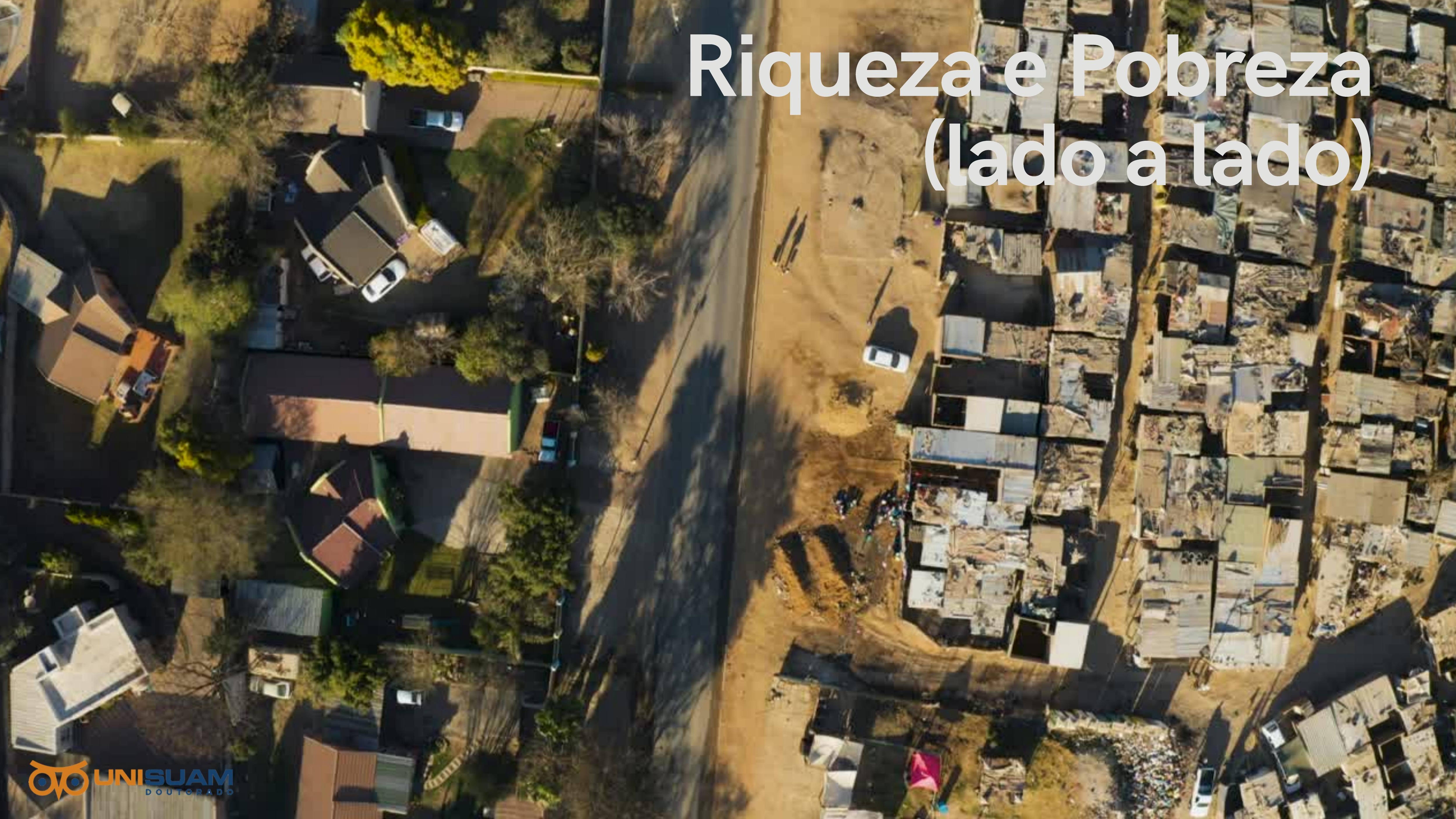




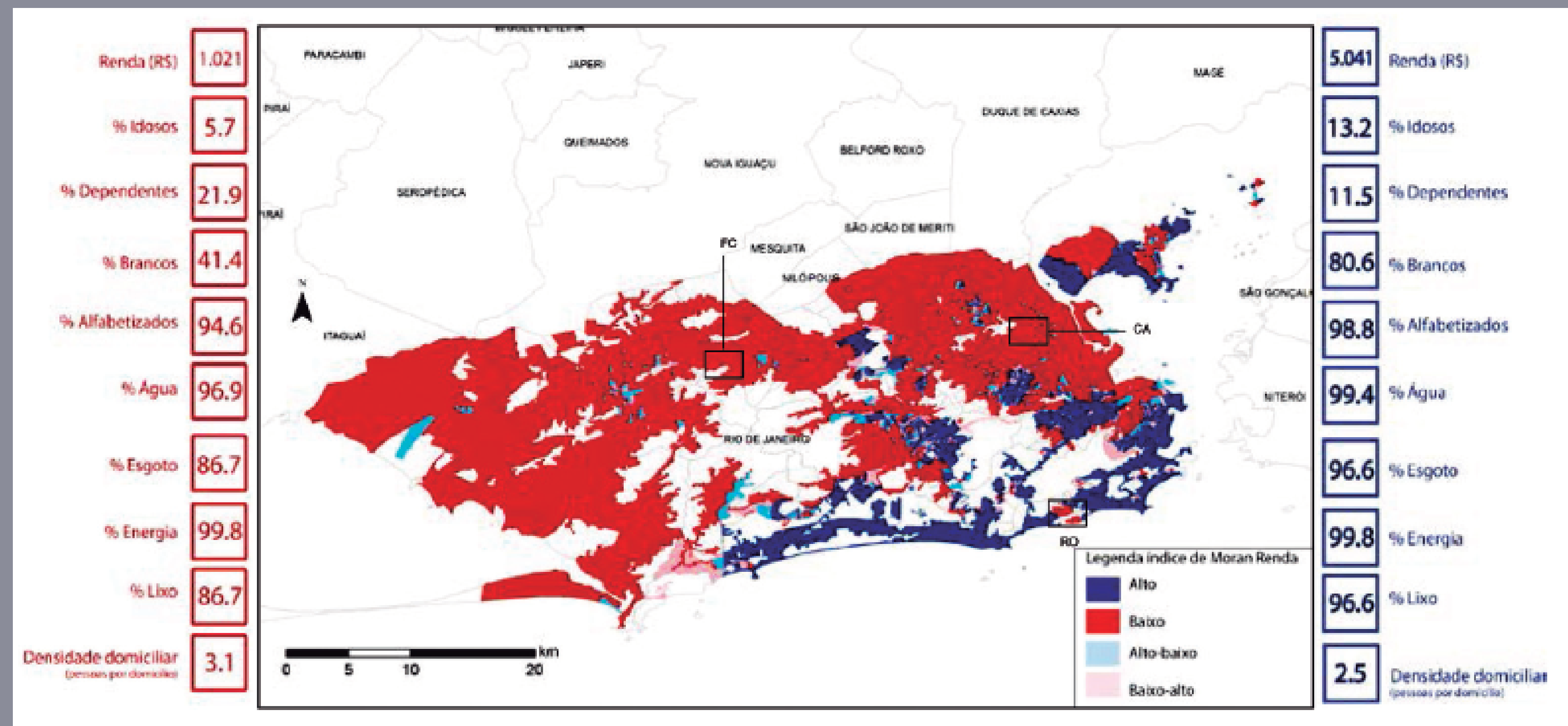

- Agrupamento de alta renda representado pela cor azul escuro (zona sul);

- Agrupamento de baixa renda representado pela cor vermelha (zona norte e oeste). 


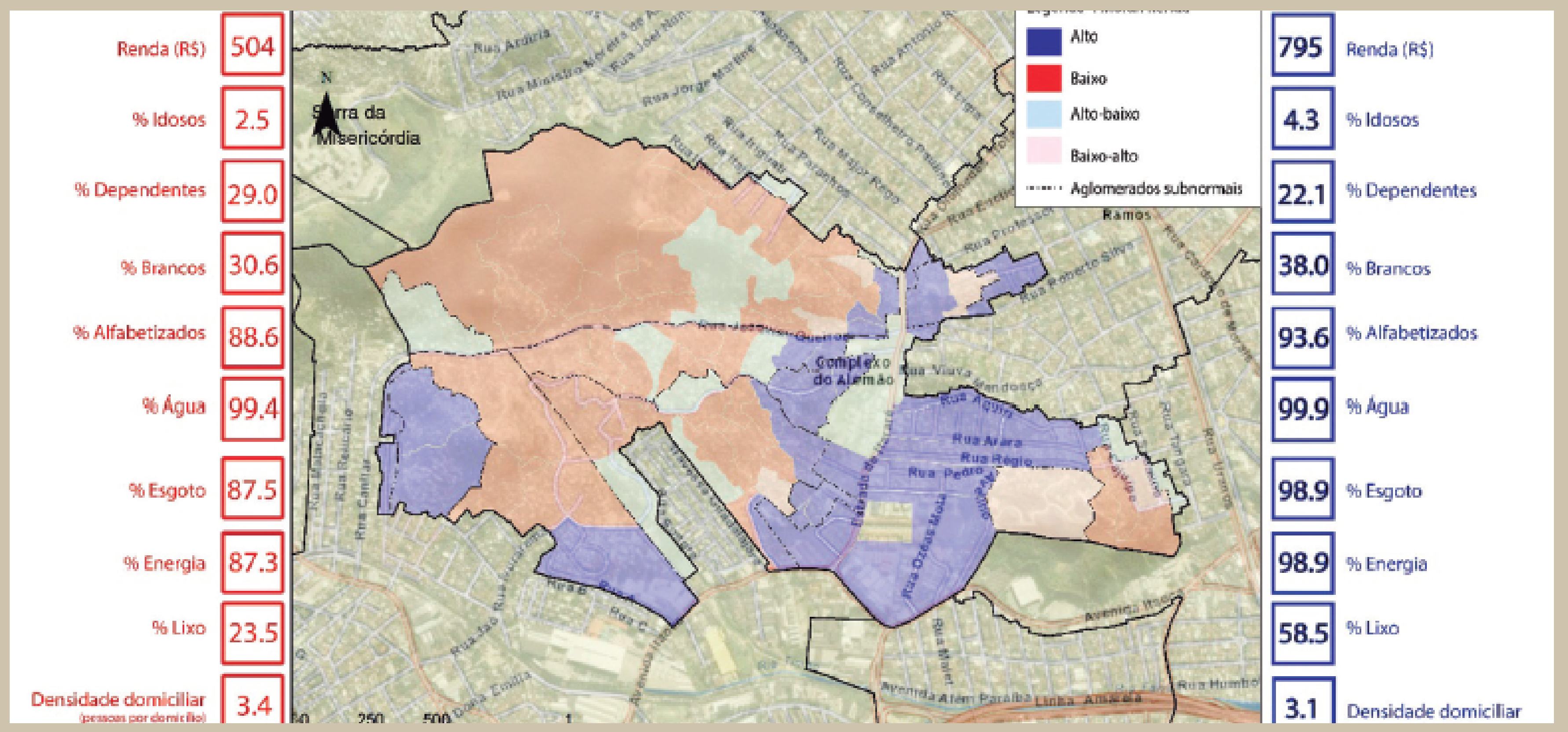

- Agrupamento de alta renda representado pela cor azul escuro (parte baixa da favela);

- Agrupamento de baixa renda representado pela cor vermelha (parte alta da favela, próximo a Serra da Misericórdia). 

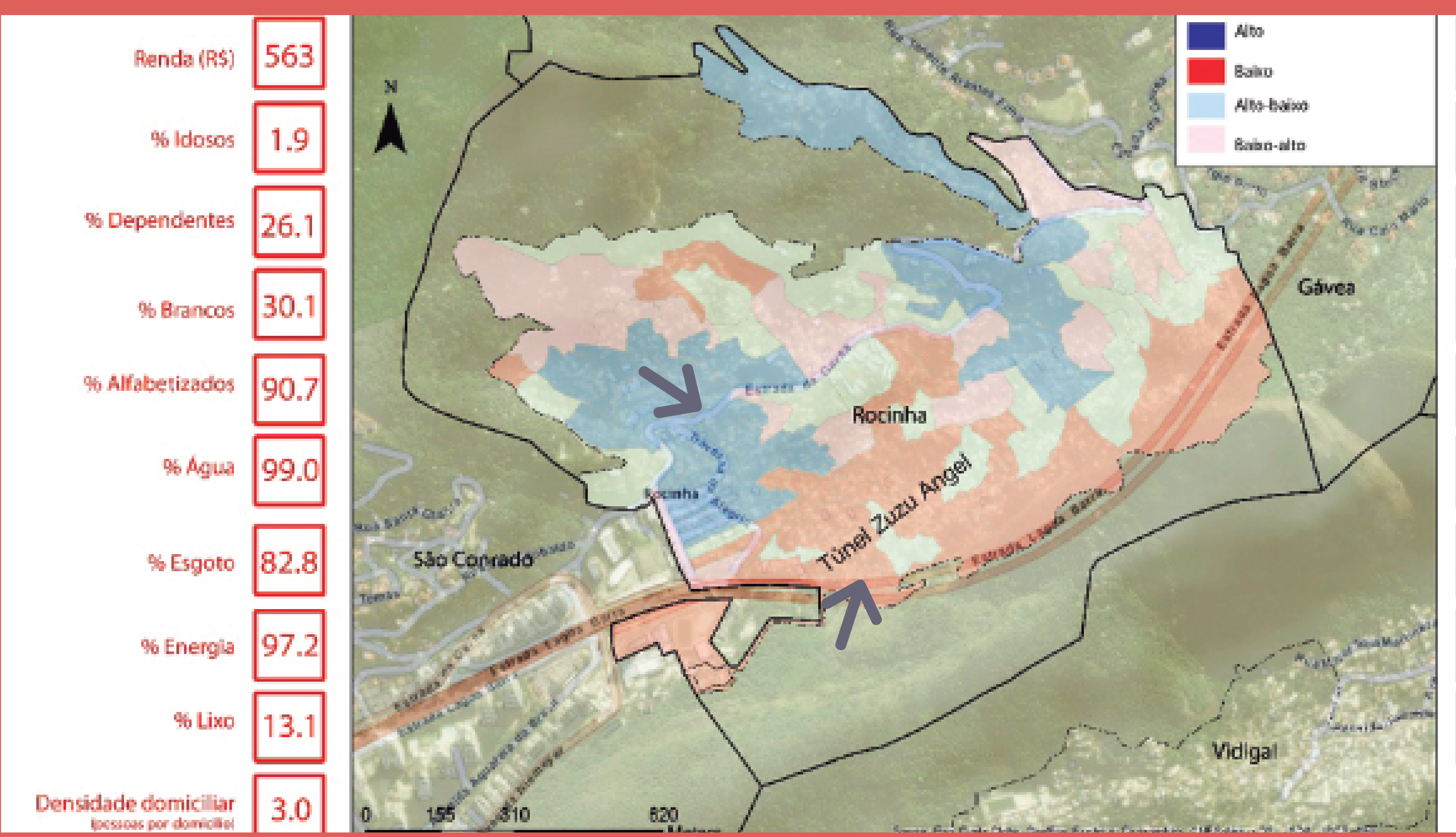

766 Fienda (fi5)

2.0 㩆 illosos

22.9 \% Depentidentes

$\frac{10}{10}$

(1)

(1)

$\sqrt{10}$ 3.0 100

- Agrupamento de alta renda representado pela cor azul (próximo ao acesso da Estrada da Gávea);

- Agrupamento de baixa renda representado pela cor vermelha (acima do Túnel Zuzu Angel). 


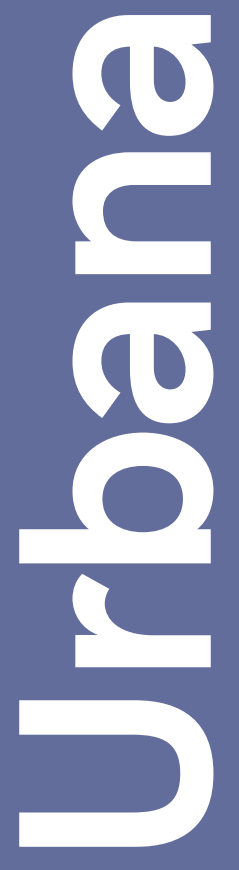

(1)

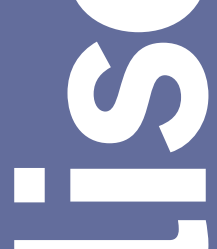

(10 $\frac{8}{4}$

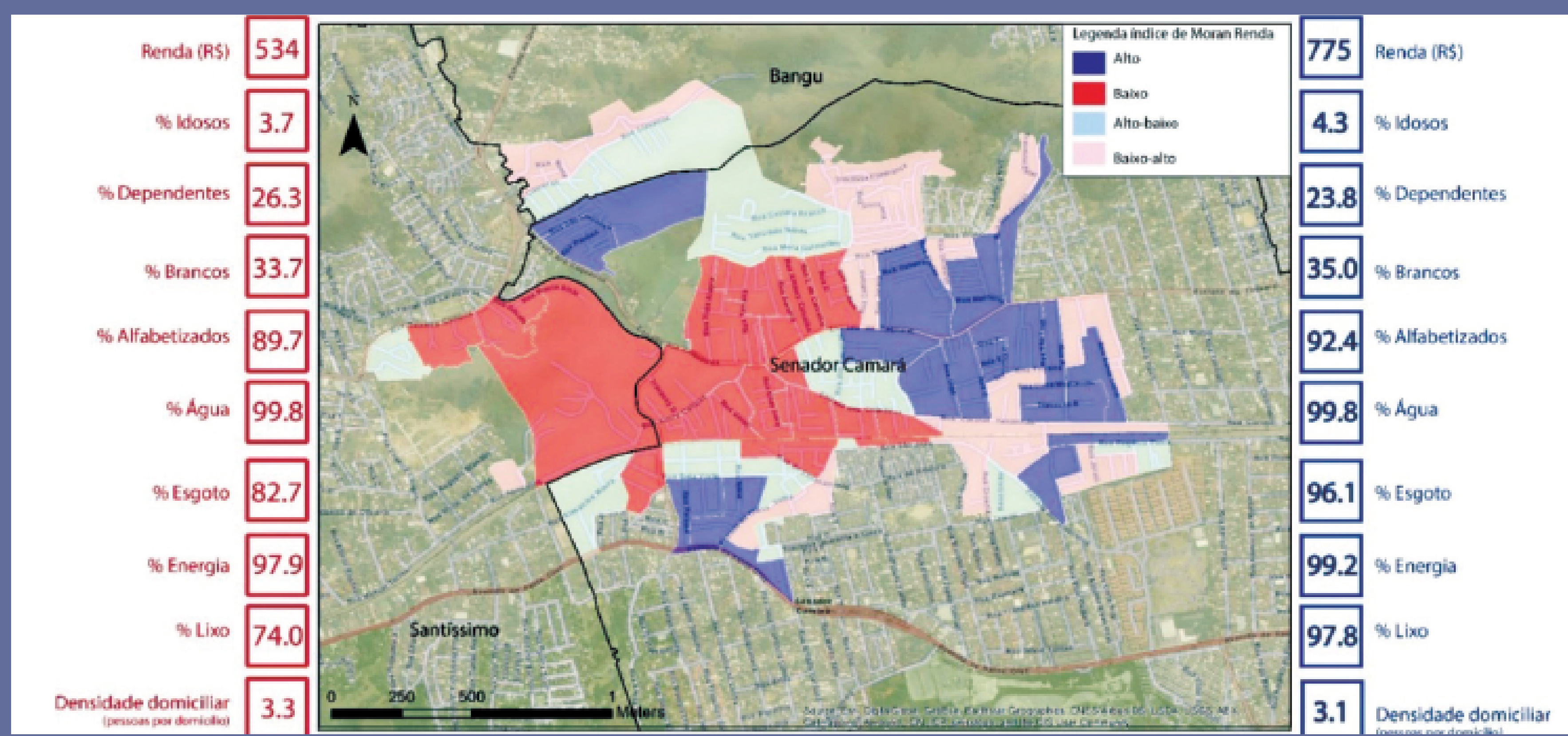

- Agrupamento de alta renda representado pela cor azul;

- Agrupamento de baixa renda representado pela cor vermelha. 
PROJETO e FAVELA: metodologia para projetos de urbanização LAURA MACHADO MELLO BUENO

Texto 2 (tese de doutorado)

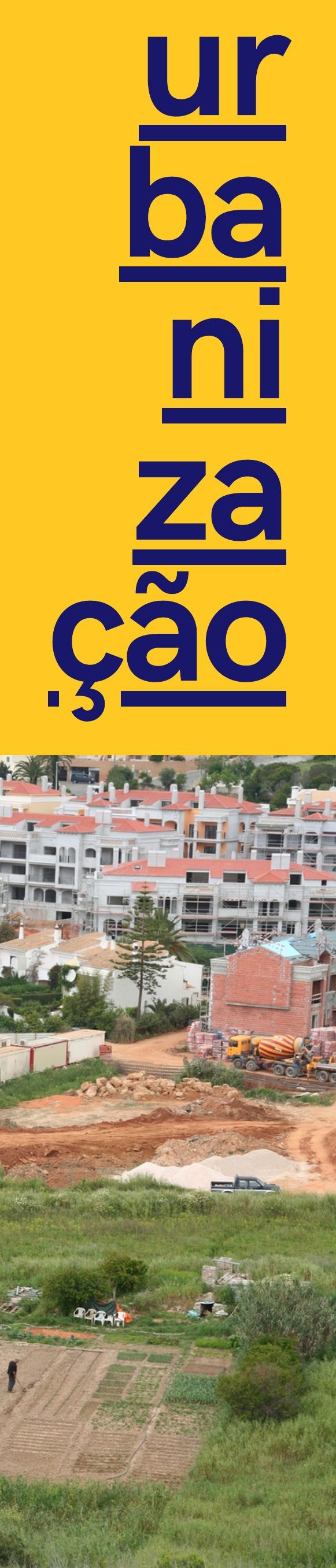




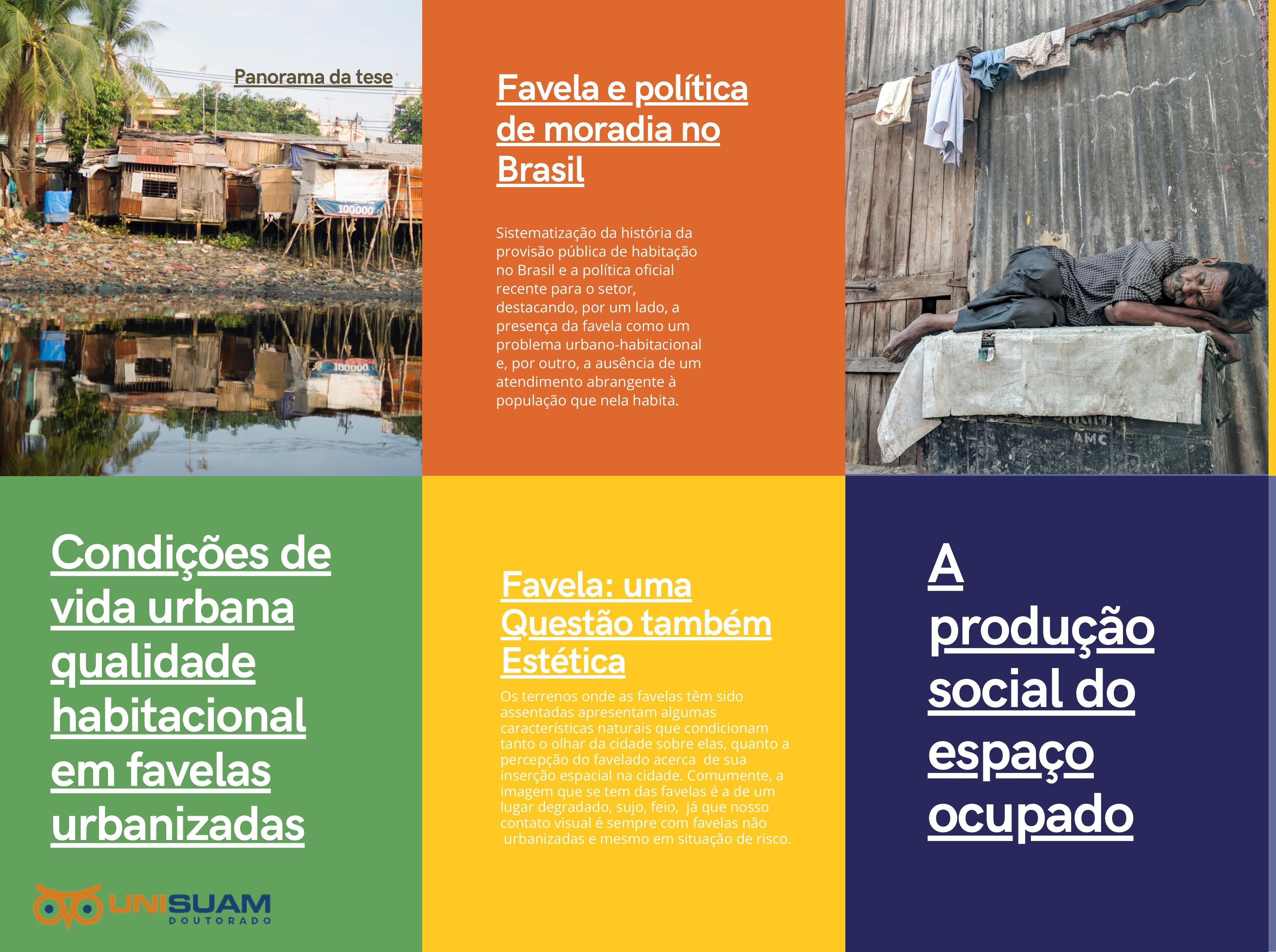

Desenvolvimento dos métodos de ação e projeto em favela

Contribuição para o desenvolvimento de projetose obras em favela

Três ações públicas fundamentais para o sucesso de programas de urbanização de favelas: 1. ATENDIMENTO ÀS OCORRÊNCIAS EMERGENCIAIS / 2. PRODUÇÃO DE NOVAS UNIDADES HABITACIONAIS PARA MORADORES DE FAVELA / 3. COMPLEMENTAÇÃO DA URBANIZAÇÃO DA PERIFERIA 


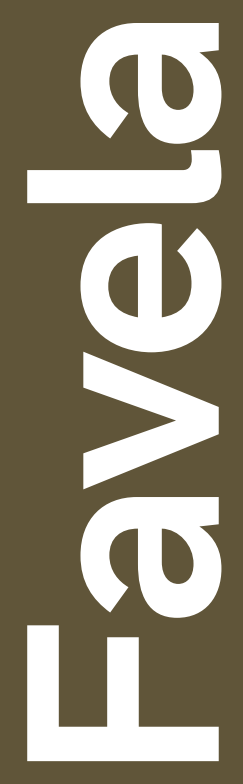

(1)

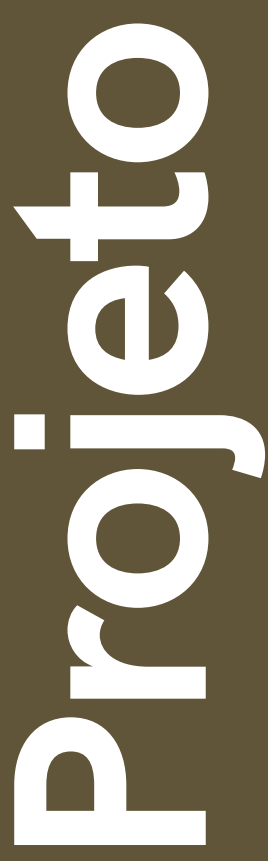

\section{Favela e política habitacional recente no Brasi}

- Sistema Financeiro de Habitação (Banco Nacional de Habitação - BNH);

- O SFH possibilitou a capitalização das empresas ligadas à provisão de habitações, permitiu a estruturação de uma rede de agentes financeiros privados, permitiu a realização do financiamento à produção e também o financiamento do consumo.

\section{A (não) política pós BNH}

- Os contratos do BNH transferidos para a CEF (Caixa Econônica Federal), A crise econômica dos anos 80 acabou por implodir o sistema do BNH.

- O sistema de construção habitacional era no modelo COHABs (Companhia de Habitação Popular).

\section{A revisão do conceito do déficit habitacional}

- Tradicionalmente, o cálculo do déficit habitacional brasileiro vinha sendo feito com base no crescimento demográfico e coabitação familiar (necessidade de novas

unidades) e na soma dos domicílios inadequados (rústicos, insalubres e deteriorados). Esses números, muitas vezes até superestimados (SILVA, 1994) o déficit habitacional é calculado a partir de quatro componentes que, quando somados, mostram claramente quais regiões precisam da construção de novas habitações, podendo abrir caminhos para investimentos do setor imobiliário. Habitações precárias, Coabitação familiar, Aluguel com valores excessivos e Adensamento. A soma desses quatro fatores são determinantes para o cálculo do déficit habitacional de uma região.

\section{Novos atores na política habitacional}

- As Cohabs acabaram por criar um "modelo" de habitação para baixa renda caracterizado.

\section{A posição das agências internacionais de financiamento}

- Até o fim dos anos 80, o BNH (e seus sucedâneos), o BID e o Banco mundial mantiveram inalterados seus princípios de formulação de políticas habitacionais: propriedade privada da moradia e a renda como requisito único para o acesso aos programas habitacionais.
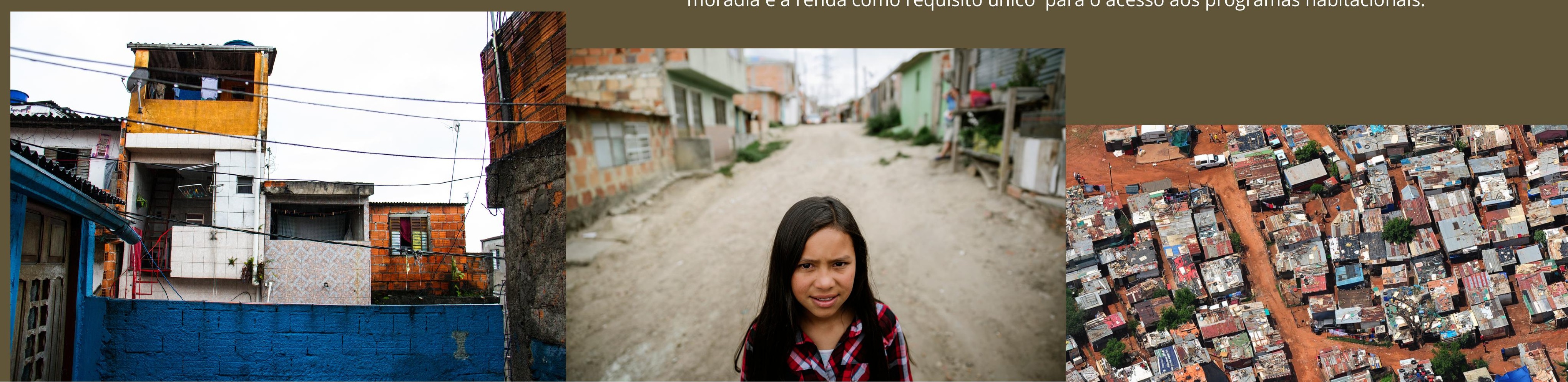


\section{Desenvolvimento dos métodos de ação e projeto em favela}

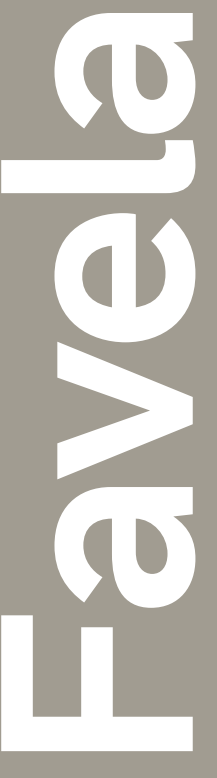

(1)

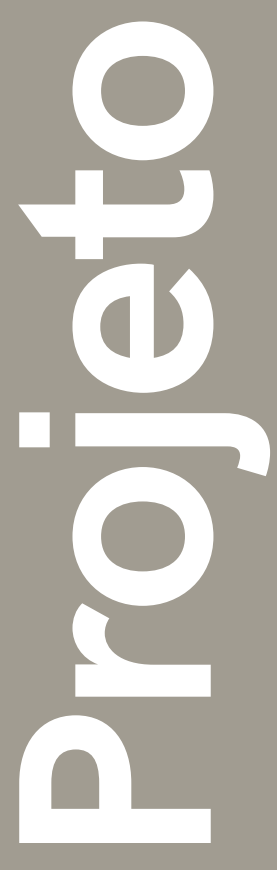

- • UN SOUAM

\section{APOIO FINANCEIRO}

A maioria das obras foi apoiada financeiramente por prefeituras ou concessionárias de serviços públicos (água, esgoto, lixo e energia). Sempre, entretanto, parte das obras, especialmente as casas e a manutenção urbana, é paga pelos moradores, sem financiamento.

Três tipos principais de políticas de intervenção tem sido adotadas ao longo dos anos:

DESFAVELAMENTO, remoção ou erradicação de favelas. Esse era o discurso do BNH em seus anos iniciais. Entretanto, essa proposta já havia sido tentada desde os anos 40, em diferentes cidades brasileiras, com sucesso nas áreas centrais. Essa proposta ainda vem sendo implementada em situações específicas relacionadas a grandes interesses imobiliários;

ACEITAÇÃO DA FAVELA, enquanto fenômeno urbano, mas não aceitação da forma e da tipologia urbanística e habitacional que ela revelava, levando à demolição da favela e reconstituição de tudo no mesmo lugar, com um padrão urbanístico e arquitetônico semelhante à linguagem dominante. Esse tipo de intervenção, a que denominaremos reurbanização, também tem sido aplicado em favelas suscetíveis a marés e com problemas de inundação;

URBANIZAÇÃO, ou seja, dotação de infra-estrutura, serviços e equipamentos urbanos nas favelas, mantendo-se as características do parcelamento do solo e as unidades habitacionais, postura que tem sido adotada, mais amplamente a partir do começo dos anos 80 .
Esses três partidos urbanísticos têm uma sequência histórica, ligados que estão à aceitação de que a favela não é um fenômeno localizado ou esporádico no processo urbano brasileiro, e à ampliação do espaço das políticas públicas voltadas a essas populações.

Erradicação, reurbanização e urbanização também convivem no tempo e no espaço.

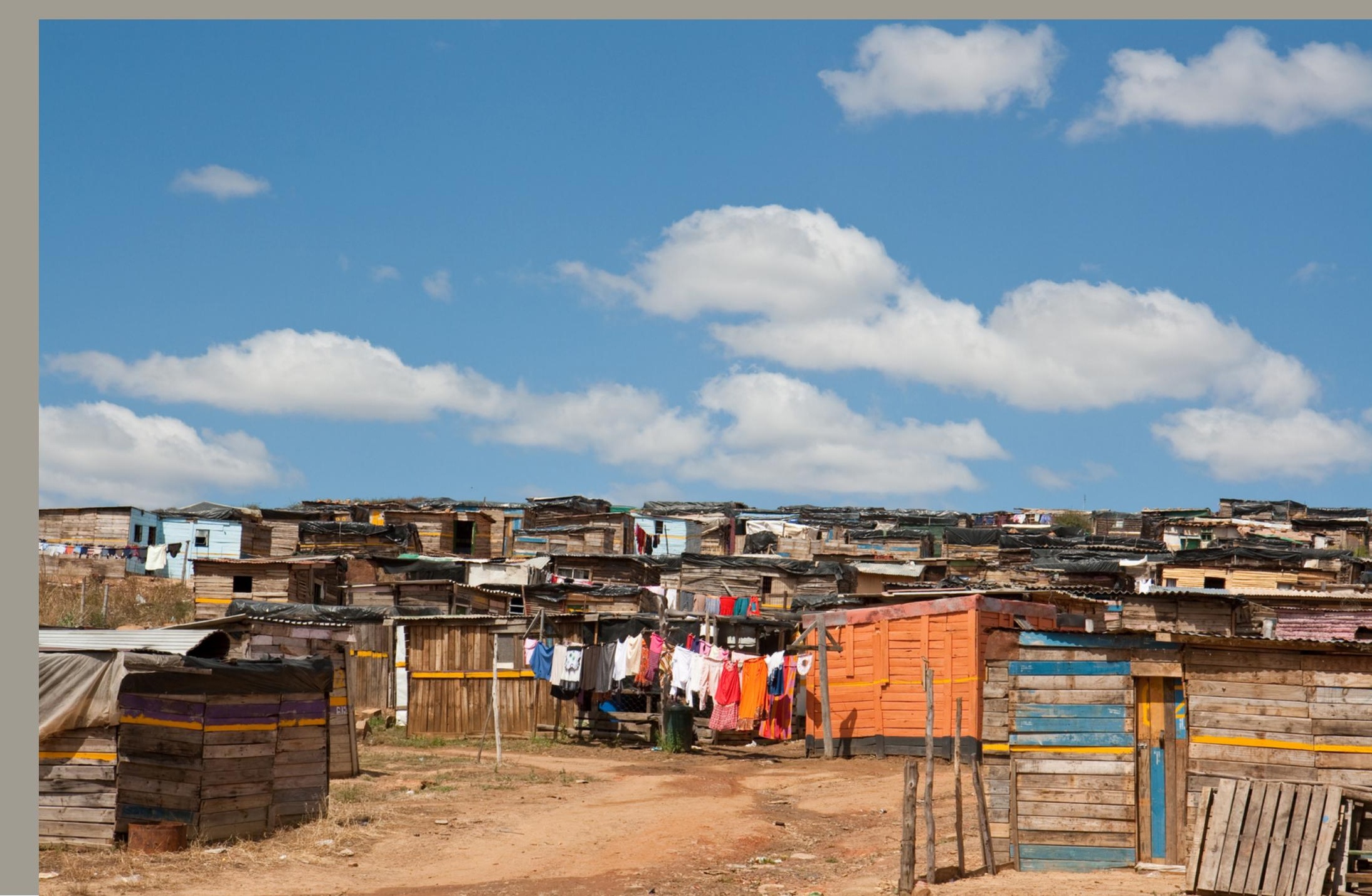


$\frac{10}{10}$

(1)

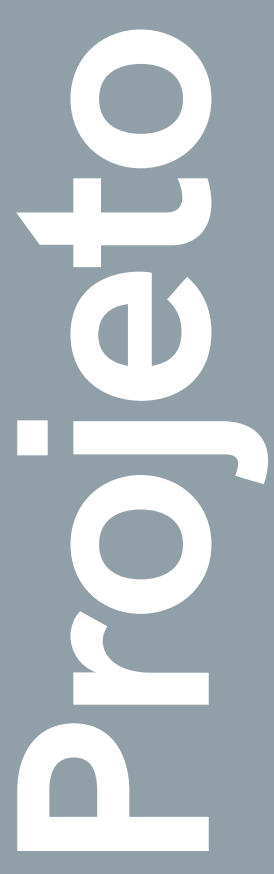

- - UN SuUAM
Análise dos resultados da urbanização de oito favelas em cinco cidades brasileiras. Os dados foram coletados no âmbito da pesquisa "Parâmetros para urbanização de favelas".

Reflexões:

A primeira, quanto à avaliação das obras de urbanização propriamente ditas, em seu resultado urbanístico, ambiental e paisagístico. Esta reflexão estará profundamente ancorada nas características socioeconômicas e em determinadas condições de vida de cidades da periferia do capitalismo.

Uma segunda reflexão desenvolvida aqui diz respeito à abrangência da melhoria das condições habitacionais após a urbanização.

Favelas Pesquisadas: 1. Castelo Encantado, Fortaleza / 2. Favelas Jardim

Conquista e 3. Jardim Dom Fernando I, Goiânia / 4. Vila Olinda e 5. Barão de Uruguaiana, Diadema / 6. Jardim Esmeralda e 7. Santa Lúcia II, São Paulo / 8. Ladeira dos Funcionários/ Parque São Sebastião, Rio de Janeiro

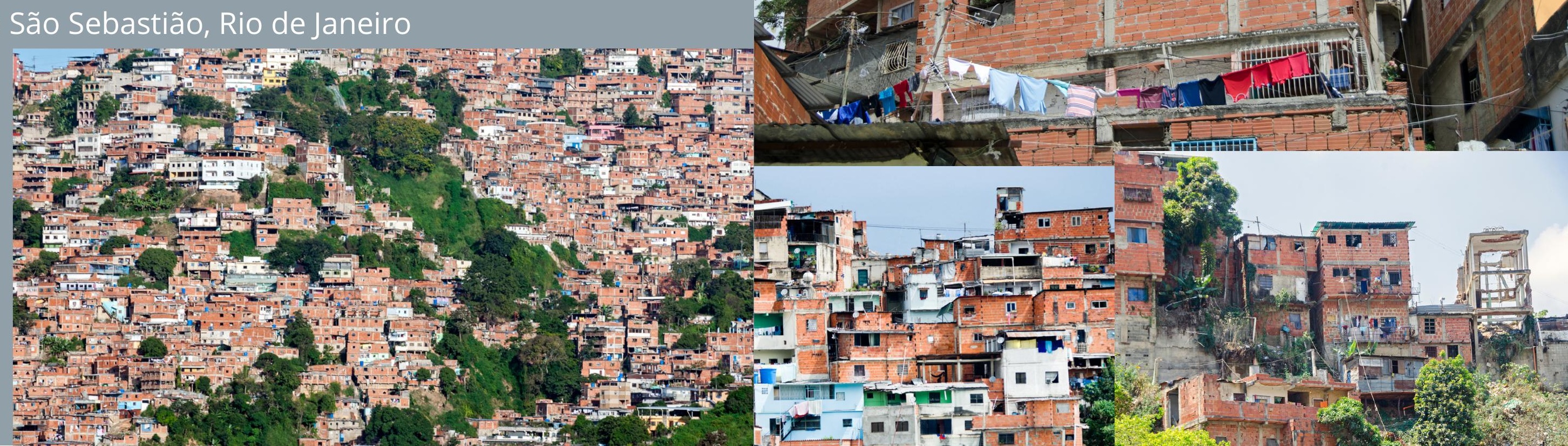




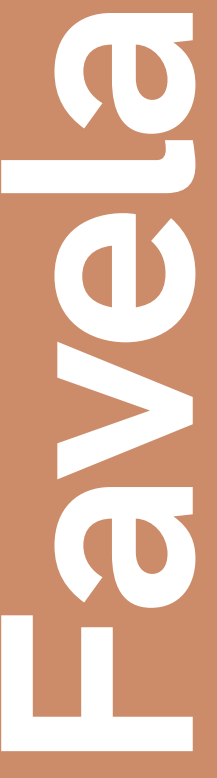

(1)

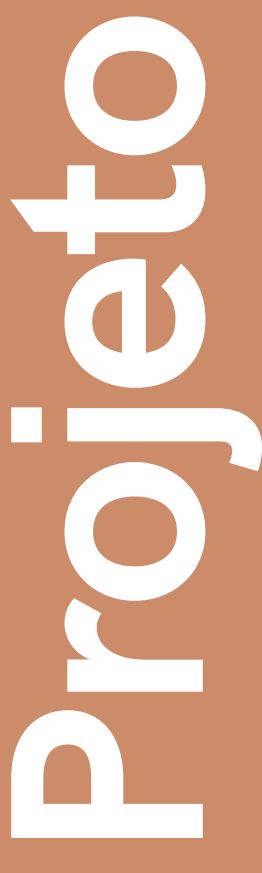

- - UN SunAM
A percepção visual que temos das favelas depende de alguns fatores, tais como sua dimensão, a topografia da cidade em que se encontram, sua inserção maior ou menor na malha urbana e sua semelhança maior ou menor com a área edificada do entorno. Vistas de cima, apresentam-se, na maioria das vezes, demarcadas por córregos, morros, pedras. As encostas têm uma textura própria, sem muita variedade, a não ser nos núcleos ou enclaves urbanizados.

Quando atendidas pelos serviços urbanos, as favelas articulam uma grande variedade arquitetônica - nos acabamentos das construções, na pintura das esquadrias ou paredes - com uma uniformidade determinada especialmente pela pavimentação (escadas, vielas, calçadas) dos espaços de uso coletivo e de provisão de serviços públicos.

No caso da zona sul do Rio de Janeiro, por exemplo, as grandes favelas nos morros formam uma paisagem marcante e contrastante com a massa de edifícios do entorno.

Exemplo: Rocinha, Vidigal
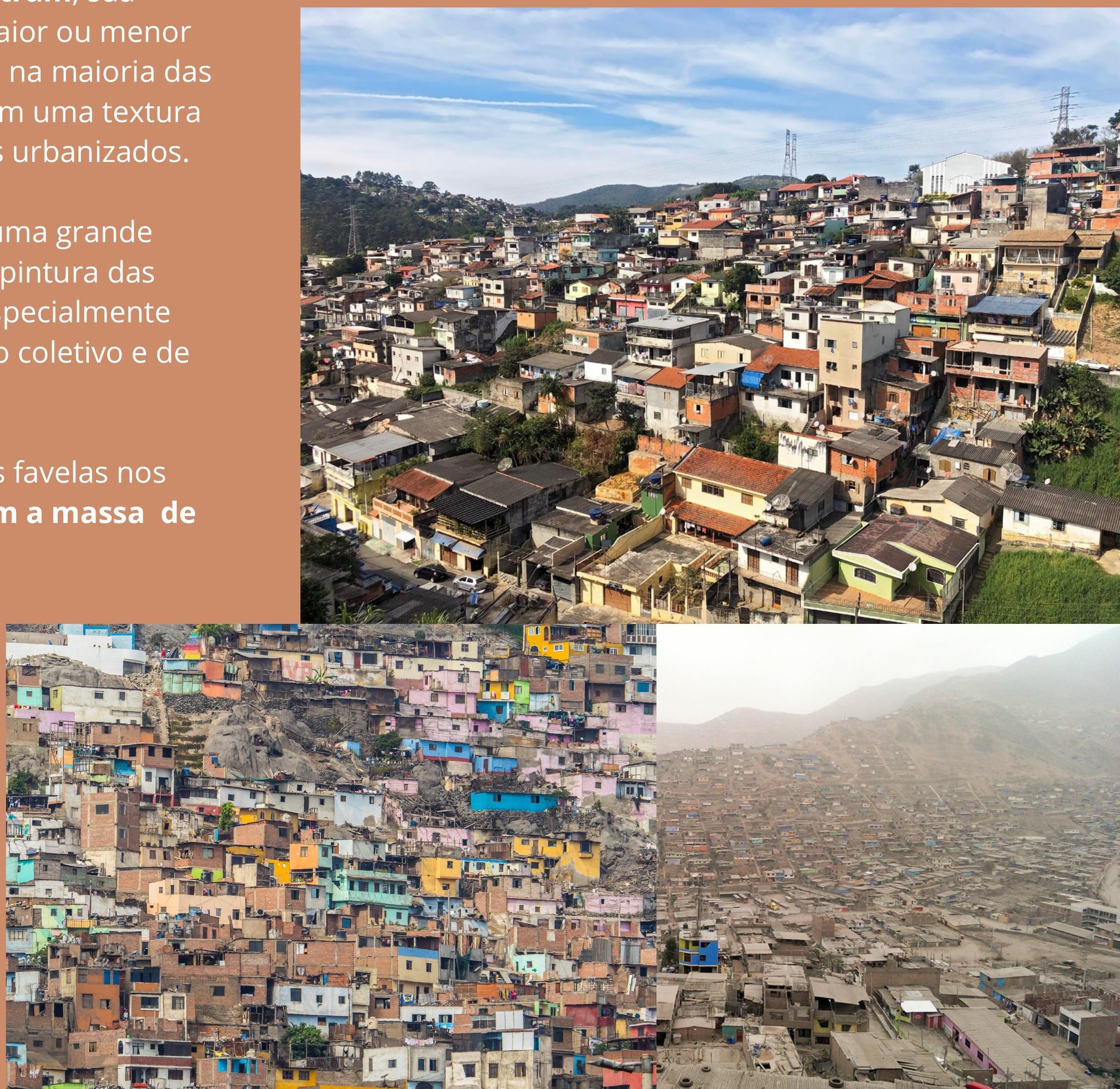
Apesar da criatividade dos moradores e da acomodação dos assentamentos à morfologia natural dos terrenos, com poucas intervenções de grande escala (como terraplenagem e drenagem, comuns nas obras projetadas), as favelas apresentam três problemas ambientais muito graves, que têm comprometido a vida de seus habitantes, seja por suas conseqüências para a saúde, e até para a manutenção da própria vida, seja pelo custo econômico acarretado - gastos com remédios, perda de produtividade no trabalho, perda de bens quando da ocorrência de desastres. São eles:

Problemas sanitários e desconfortos relacionados à inexistência ou precariedade dos serviços de abastecimento de água e de coleta de esgotos e de lixo e às dificuldades dos acessos;

O problema do conforto térmico e da salubridade das edificações, relacionado à precariedade das construções - inexistência de aberturas para entrada de luz e aeração das casas e falta de insolação devido à grande densidade habitacional.

Existência de áreas de risco de acidentes - inundações, desbarrancamentos, deslizamento de encostas.

A leitura da favela como um espaço em contínua mutação, que pode continuar se expandindo horizontal ou verticalmente, ou se transformar em conseqüência de ações no seu espaço público ou no domínio privado, é sinal evidente de sua não transitoriedade, pelo menos para seu morador. Em todas as favelas que são urbanizadas verifica-se o aumento no número de obras de reformas para melhoria e ampliação das casas.

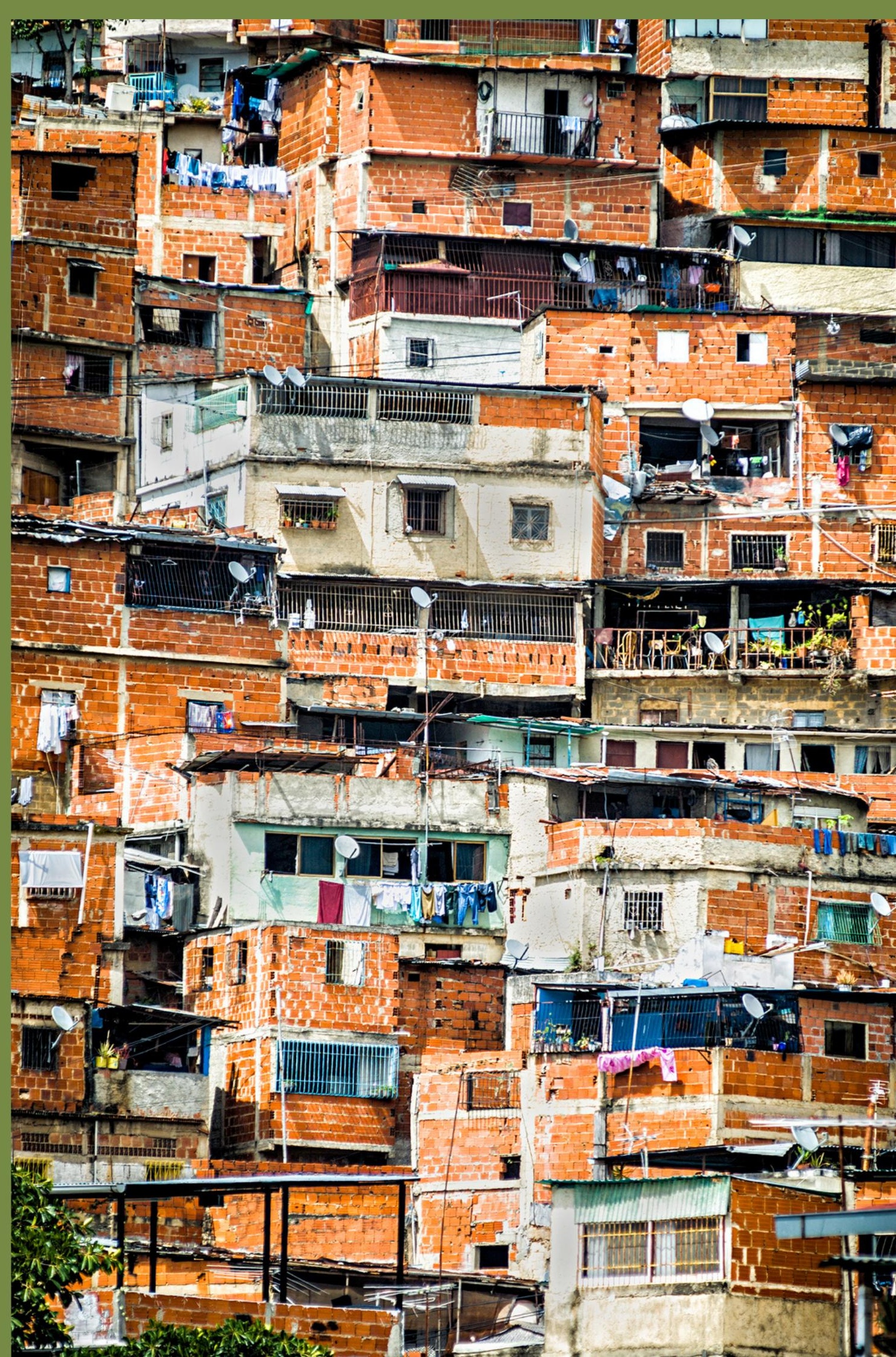


A urbanização de favelas é aqui entendida como um ação que deva se predominantemente assumida pelo Estado, seja na execução, na promoção ou somente no financiamento dos projetos. Assim, é fundamental que se compreenda a necessidade da integração entre as ações em favelas e outras políticas abrangentes de moradia e de recuperação urbana ambiental.

A seguir três ações públicas fundamentais para o sucesso de programas de urbanização de favelas.

\section{ATENDIMENTO ÀS OCORRÊNCIAS EMERGENCIAIS}

ocorrências de enchentes, deslizamentos de terra, desabamentos, freqüentes em época de chuvas, bem como de incêndios e outros acidentes, devem ser atendidas por um sistema planejado de defesa civil

PRODUÇÃO DE NOVAS UNIDADES HABITACIONAIS PARA MORADORES DE FAVELA programa de urbanização de favelas, a remoção planejada de famílias é imprescindível em duas situações: áreas de risco e áreas com alta densidade.

\section{COMPLEMENTAÇÃO DA URBANIZAÇÃO DA PERIFERIA}

Terrenos onde se encontram as favelas - fundos de vale, encostas de morros, beiras de córregos e vias - fazem parte de setores urbanos que tiveram dotação de infra-estrutura, equipamentos, mobiliário e serviços urbanos parcial, incompleta ou malfeita, tais como os loteamentos populares, irregulares ou clandestinos, ou as áreas do entorno de grandes obras públicas executadas com visão setorial

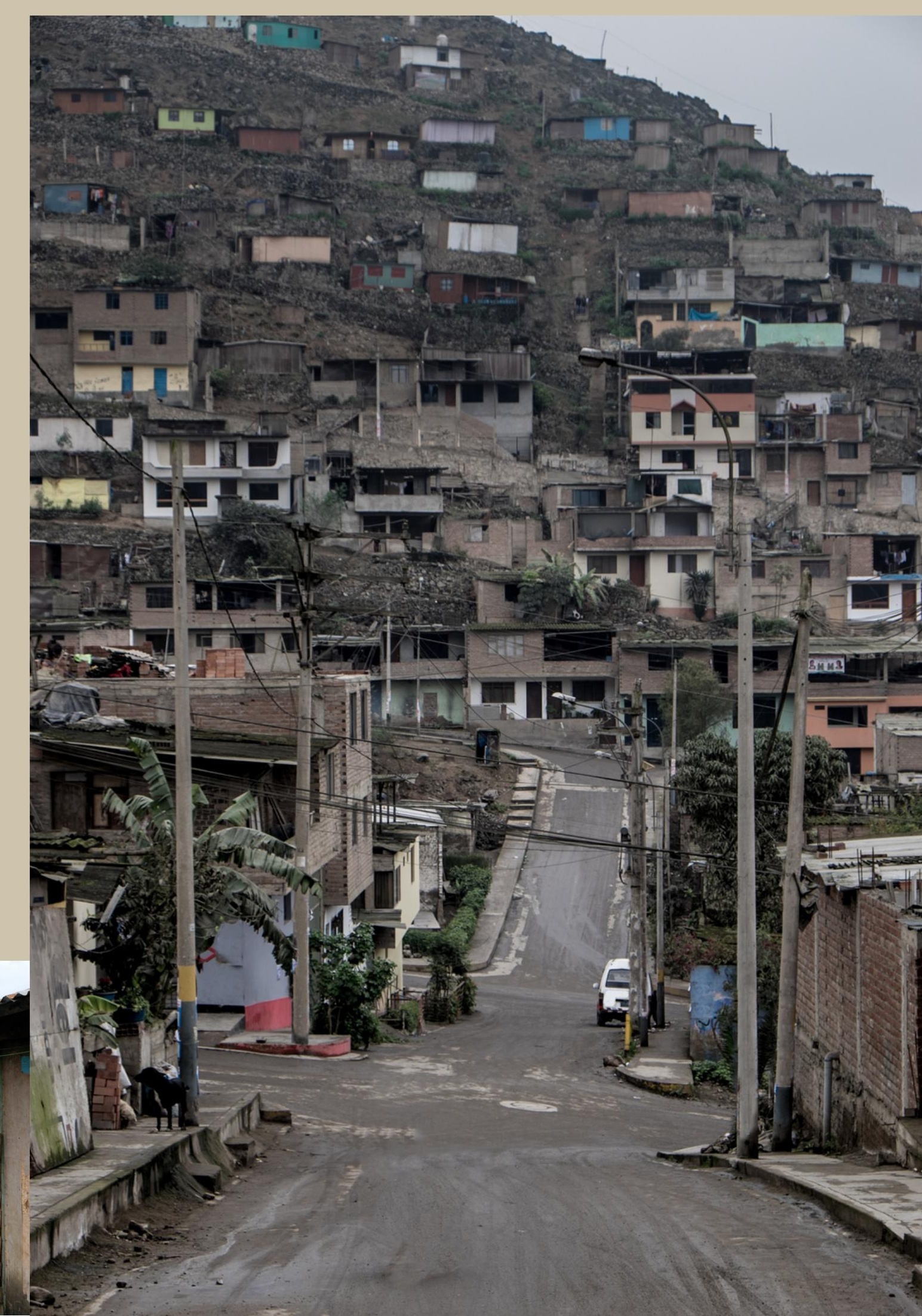


definição resumida do conceito de pobreza dada pelos pobres é dada a seguir: “Pobreza é fome, é falta de abrigo. Pobreza é estar doente e não poder ir ao médico. Pobreza é não poder ir à escola e não saber ler. Pobreza é não ter emprego, é temer o futuro, é viver um dia de cada vez. Pobreza é perder o seu filho para uma doença trazida pela água não tratada. Pobreza é falta de poder, falta de representação e liberdade". 


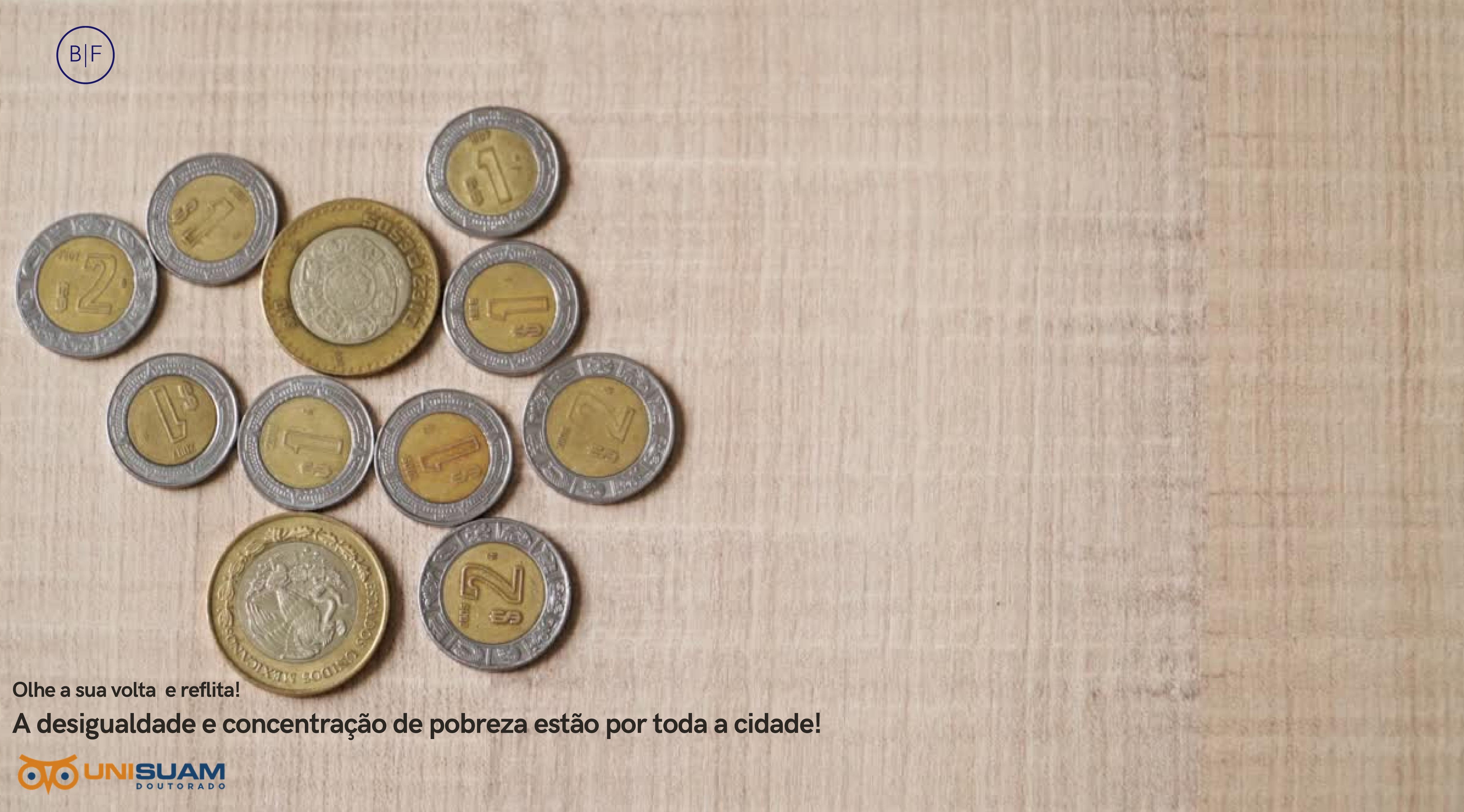




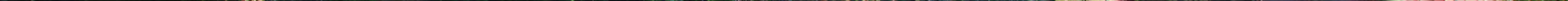

